\title{
Lipoprotein (a), lipids, and lipoproteins in patients with rheumatoid arthritis
}

\author{
Solbritt Rantapää-Dahlqvist, Solveig Wållberg-Jonsson, Gösta Dahlén
}

\begin{abstract}
Lipoprotein (a), (Lp(a)), an independent atherogenic factor, was significantly increased in 93 patients with classical, seropositive rheumatoid arthritis of median disease activity. In the patients with $L p(a)$ concentrations above the upper reference value of $480 \mathrm{mg} / \mathrm{l}$ there was a significant correlation between $\mathbf{L p}(\mathrm{a})$ and the concentration of orosomucoid, erythrocyte sedimentation rate, and the platelet count. The plasma concentrations of cholesterol and high density lipoproteincholesterol in both male and female patients were significantly lower than in controls. Apolipoprotein B and apolipoprotein $\mathrm{AI}$ in the patients correlated significantly with total cholesterol and high density lipoproteincholesterol respectively.
\end{abstract}

An increased mortality has been reported in hospital inpatients with rheumatoid arthritis compared with the general population. ${ }^{1-5}$ The most common cause of death in patients with rheumatoid arthritis, as in the general population, was cardiovascular disease. ${ }^{15}$ Some studies found an even higher incidence of cardiovascular disease in patients with rheumatoid arthritis than in controls. ${ }^{146}$

Increased concentrations of total cholesterol, low density lipoprotein-cholesterol, and total apolipoprotein B have been found to be associated with an increased risk for cardiovascular disease. $^{7-9}$ Even low concentrations of high density lipoprotein-cholesterol and apolipoprotein AI have been found to be risk factors for cardiovascular disease. ${ }^{7-9}$

In patients with inflammatory polyarthritis the serum concentrations of cholesterol and some subfractions of triglycerides have been found to be significantly lower than in controls. ${ }^{10-12} \mathrm{~A}$ significant inverse correlation between inflammatory activity and lipoprotein or lipid concentrations has previously been reported. ${ }^{12}{ }^{13}$ The apolipoprotein AI/apolipoprotein $B$ ratio has been found to be raised in rheumatoid arthritis. ${ }^{14}$

Because lipoprotein (a) ( $\mathrm{Lp}(\mathrm{a})$ ) may exert independent strong atherogenic effects $s^{15}$ and be associated with acute phase reactant ${ }^{17}$ we analysed the concentrations of $\operatorname{Lp}(a)$ in patients with active rheumatoid arthritis. Apolipoprotein AI, apolipoprotein B, and lipids (cholesterol and triglycerides) were also determined. The concentrations of lipids and $L p(a)$ in plasma were related to the laboratory data showing disease activity and to drug treatment.

\section{Patients and methods} PATIENTS

Ethylenediaminetetra-acetate (EDTA) plasma was collected consecutively from 93 inpatients ( 75 female, 18 male) with classical, erosive, and seropositive rheumatoid arthritis. ${ }^{18}$ All patients had median disease activity (according to the criteria of the Cooperating Clinics Committee of the American Rheumatism Association). Table 1 shows the laboratory data for the patients at the time of the study. The mean age of the patients was 62.8 years (range 25-80), and the mean disease duration 20.9 years (range $0.5-51$ ). All patients were receiving an ordinary hospital diet and the weight/height index was less than $1 \cdot 1$ (weight in $\mathrm{kg}$ divided by height in $\mathrm{cm}$ minus 100 ).

Fifty of the patients were receiving corticosteroids (prednisolone $2.5-20 \mathrm{mg}$ daily) and 19 remission inducing drugs (penicillamine, disodium aurothiomalate, sulphasalazine, azathioprine, mitopodozide). Fifty nine were receiving both corticosteroids and remission inducing drugs. Seventy two patients took nonsteroidal anti-inflammatory drugs. None of the patients had laboratory or clinical signs of kidney, liver, thyroid, or infectious diseases, diabetes mellitus, or malignancy. Nine patients $(10 \%)$ were receiving $\beta$ blockers and eight $(9 \%)$ thyroxine treatment.

\section{CONTROLS}

Control samples (EDTA plasma) were collected from 67 healthy subjects matched for age (33 female, 34 male) and from the same area as the patients. The controls belonged to a health project (the Norsjö project) that included subjects from a certain area.

\section{METHODS}

Erythrocyte sedimentation rate (Westergren), haptoglobin, orosomucoid, $\mathrm{C}$ reactive protein, and platelets were measured by routine methods at the laboratory of clinical chemistry. Cholesterol, high density lipoprotein-cholesterol, and triglycerides were determined enzymatically with reagent kits from Boehringer Mannheim, FRG. Lipoprotein (a) was measured by an enzyme linked immunosorbent assay (ELISA). The detection limit was $10 \mathrm{mg} / \mathrm{l}$ and the assay range $10-600 \mathrm{mg} / 1$. Mean intra-assay variation (CV) was 6.6 and $2.3 \%$ at $L p(a)$ concentrations of 40 and $300 \mathrm{mg} / 1$, and interassay variation was 7.7 and $2.7 \%$ respectively. The correlation with electroimmunoassay was $0 \cdot 91 .{ }^{15}$ Apolipoprotein 
Table 1 Laboratory data (mean (SEM) and ranges) in 93 patients with rheumatoid arthritis, and normal values

\begin{tabular}{|c|c|c|c|c|c|}
\hline & $\begin{array}{l}E S R^{*} \\
(\mathrm{~mm} / \mathrm{h})\end{array}$ & $\begin{array}{l}\text { Orosomucoid } \\
(\mathrm{g} / \mathrm{l})\end{array}$ & $\begin{array}{l}\text { Haptoglobin } \\
(\mathrm{g} / \mathrm{l})\end{array}$ & $\begin{array}{l}C R P^{*} \\
(m g / l)\end{array}$ & $\begin{array}{l}\text { Thrombocytes } \\
\left(\times 10^{9} / l\right)\end{array}$ \\
\hline Patients ( $n=93$ ) & $\begin{array}{l}53 \cdot 1(17 \cdot 7) \\
(20-109)\end{array}$ & $\begin{array}{l}1 \cdot 8(0.52) \\
(0 \cdot 8-3 \cdot 1)\end{array}$ & $\begin{array}{l}3 \cdot 7(1 \cdot 1) \\
(1 \cdot 2-6 \cdot 3)\end{array}$ & $\begin{array}{l}25(20 \cdot 4) \\
(1-96)\end{array}$ & $\begin{array}{l}368(11 \cdot 4) \\
(131-685)\end{array}$ \\
\hline Reference values & $<20$ & $0 \cdot 1-1 \cdot 0$ & $0 \cdot 3-2 \cdot 5$ & $<5$ & $150-350$ \\
\hline
\end{tabular}

*ESR=erythrocyte sedimentation rate; $\mathrm{CRP}=\mathrm{C}$ reactive protein.

Table 2 Plasma concentrations (mean (SEM) and ranges) of lipoprotein $(a)(L p(a))$ cholesterol, and triglycerides in 93 patients with rheumatoid arthritis and in 67 controls matched for age from the same area

\begin{tabular}{llll}
\hline & $\begin{array}{l}L p(a) \\
(m g / l)\end{array}$ & $\begin{array}{l}\text { Cholesterol } \\
(\text { mmolll })\end{array}$ & $\begin{array}{l}\text { Triglycerides } \\
(\text { mmolll })\end{array}$ \\
\hline Patients $(\mathrm{n}=93)$ & $230 \cdot 3(25 \cdot 20)^{*}$ & $5 \cdot 49(0 \cdot 13)^{* * *}$ & $\begin{array}{l}1 \cdot 42(0 \cdot 05) \\
(2 \cdot 45-9 \cdot 00)\end{array}$ \\
Controls $(\mathrm{n}=67)$ & $(0-1425)$ & $7 \cdot 41(0 \cdot 21)$ & $1 \cdot 74(0 \cdot 12)$ \\
& $153 \cdot 5(22 \cdot 13)$ & $(4 \cdot 20-11 \cdot 60)$ & $(0 \cdot 70-5 \cdot 30)$ \\
\hline
\end{tabular}

${ }^{* * *} \mathrm{p}<0.001 ;{ }^{* *} \mathrm{p}<0.01 ;{ }^{*} \mathrm{p}<0.05$ patients $v$ controls.

B and apolipoprotein AI were measured with radioimmunoassay research kits from Pharmacia Diagnostics, Uppsala, Sweden.

\section{STATISTICS}

All calculations were performed by StatView (Brain Power Inc, Calabasas, Ca, USA). Plasma concentrations of the lipids and lipoproteins in the patients and controls were compared by the Mann-Whitney $U$ test. Correlation between variables was assessed by Pearson productmoment correlation coefficients and tested for two tailed probability values. A two way analysis of variance was used for analysis of two independent groups.

\section{Results}

The highest concentration of $L p(a)$ was found in the 50 patients treated with corticosteroids, mean $243.1 \mathrm{mg} / 1$ (data not shown); this, however, was not significantly different from the value for untreated patients with rheumatoid arthritis. Consequently, patient data were analysed as one group. Table 2 presents the results. The $L p(a)$ concentration was significantly increased $(\mathrm{p}<0.05)$ in patients with rheumatoid arthritis (mean (SEM) 230.3 (25.2) $\mathrm{mg} / \mathrm{l}$ ) compared with the controls (mean (SEM) $153.5(22 \cdot 13) \mathrm{mg} / \mathrm{l})$. In $12(13 \%)$ of the patients with rheumatoid arthritis the $L p(a)$ concentrations exceeded the upper reference level of $480 \mathrm{mg} / \mathrm{l}$, which was significantly higher than the $2.5 \%$ found in a reference group of 653 healthy subjects ${ }^{16}(p<0.05)$. For those patients with $\mathrm{Lp}(\mathrm{a})$ concentrations greater than $480 \mathrm{mg} / \mathrm{l}$ a significant correlation between $\mathrm{Lp}(\mathrm{a})$ concentration and orosomucoid $(r=0.63$, $\mathrm{p}<0.05)$, erythrocyte sedimentation rate $(r=0.83, p<0.001)$, and platelet count $(r=0.71$, $p<0.05$ ) was found, and there was a tendency for correlation with haptoglobin $(r=0.53$, $\mathrm{p}<0.07)$ also. In the nine patients with $\operatorname{Lp}(\mathrm{a})$ concentrations above $480 \mathrm{mg} / \mathrm{l}$ who were receiving corticosteroids the $\mathrm{Lp}(\mathrm{a})$ concentration correlated even more significantly with erythrocyte sedimentation rate $(r=0.95, p<0.0001)$, orosomucoid $(r=0.68, p<0.05)$, and platelet count
Table 3 High density lipoprotein-cholesterol in plasma from 93 patients with rheumatoid arthritis and in 65 controls matched for age from the same area. Results are given as mean (SEM) in mmolll

\begin{tabular}{|c|c|c|c|}
\hline \multicolumn{2}{|l|}{ Women } & \multicolumn{2}{|l|}{ Men } \\
\hline $\begin{array}{l}\text { Patients } \\
(n=75)\end{array}$ & $\begin{array}{l}\text { Controls } \\
(n=33)\end{array}$ & $\begin{array}{l}\text { Patients } \\
(n=18)\end{array}$ & $\begin{array}{l}\text { Controls } \\
(n=32)\end{array}$ \\
\hline $1.40(0.04)^{*}$ & $1.59(0.06)$ & $1.09(0.07)^{*}$ & $1.32(0.06)$ \\
\hline
\end{tabular}

$* \mathrm{p}<0.05$ patients $v$ controls.

$(\mathrm{r}=0.73, \mathrm{p}<0.05)$. There was no correlation between $C$ reactive protein and the $L p(a)$ concentration in any patient group.

The plasma concentration of cholesterol in patients with rheumatoid arthritis (mean 5.49 $\mathrm{mmol} / \mathrm{l}$ ) was significantly lower than in the controls (mean $7 \cdot 41 \mathrm{mmol} / \mathrm{l}$ ). The concentration of triglycerides was also decreased $(1.42 \mathrm{mmol} / \mathrm{l})$, but not significantly, compared with controls $(1.74 \mathrm{mmol} / \mathrm{l}$ ) (table 2$)$. The mean concentrations $(5.63 \mathrm{mmol} / \mathrm{l}$ and $1.48 \mathrm{mmol} / 1$ respectively) of cholesterol and triglycerides were slightly higher (non-significantly) in the patients treated with corticosteroids. There was no significant difference between patients treated with nonsteroidal anti-inflammatory drugs or remission inducing drugs. There was a significant difference in the concentration of high density lipoprotein-cholesterol between patients and controls, and between sexes of both groups. The concentrations of high density lipoproteincholesterol were significantly lower both in female patients $(1.40 \mathrm{mmol} / \mathrm{l} ; \mathrm{p}<0.05)$ and in male patients $(1.09 \mathrm{mmol} / \mathrm{l} ; \mathrm{p}<0.05)$ than in the corresponding controls (table 3 ). Total apolipoprotein B correlated significantly with total serum cholesterol $(r=0.72, \quad p<0.000001)$ apolipoprotein AI correlated significantly with high density lipoprotein-cholesterol $(r=0.78$, $\mathrm{p}<0.000001)$. The high density lipoproteincholesterol/total cholesterol ratio in these patients was $24 \%$-that is, normal.

\section{Discussion}

In this study the concentration of $\mathrm{Lp}(\mathrm{a})$ was significantly increased in patients with rheumatoid arthritis with a median disease activity. As an increased concentration of $\mathrm{Lp}(\mathrm{a})$ has been found to be closely associated with cardiovascular disease, $L p(a)$ may be an important cause of cardiovascular disease in patients with rheumatoid arthritis.

Lipoprotein (a) is a cholesterol-rich lipoprotein with a lipid composition similar to low density lipoprotein. The specific antigen (s) resides in a large protein, apolipoprotein (a), which is attached by a disulphide bridge to apolipoprotein B $100 .^{19}$ The plasma concentration of $\mathrm{Lp}(\mathrm{a})$ is, to a large extent, genetically determined. ${ }^{20}$ A single locus with several alleles seems to code both for the apolipoprotein (a) isoforms $\mathrm{22}^{22}$ and for the serum concentration of $\operatorname{Lp}(\mathrm{a}) .^{21}$ Sequencing has shown that apolipoprotein (a) has striking homology with plasminogen. ${ }^{23} 24$ Studies in vitro suggest that Lp(a) may suppress fibrinolysis and thrombolysis. $^{25}$ 
Macrophage uptake by scavenger receptors and by phagocytosis of aggregated biologically modified low density lipoprotein is thought to be important in atherogenesis. ${ }^{26}$ These mechanisms might be of importance in $\mathrm{Lp}$ (a) catabolism as small aggregates have been found to cause cholesterol ester accumulation in macrophages in vitro. ${ }^{27}$ As fat elimination through macrophages and the scavenger pathway is thought to be enhanced in patients with active rheumatoid arthritis, in whom the reticuloendothelial system is overstimulated, ${ }^{12} \mathrm{Lp}(\mathrm{a})$ might be of special atherogenic importance in rheumatoid arthritis. Other early studies in vitro also suggested that $\mathrm{Lp}(\mathrm{a})$ is a causative factor for atherogenesis as it binds strongly to glycosaminoglycans ${ }^{28}$ and is easily precipitated in the presence of divalent cations. ${ }^{29}$

The significantly higher number of patients with rheumatoid arthritis with $L p(a)$ concentrations above the upper reference level of $480 \mathrm{mg} / \mathrm{l}$ may suggest that $\mathrm{Lp}(\mathrm{a})$ is increased as a response to inflammation in these patients. We also found a significant association between high concentrations of $\mathrm{Lp}(\mathrm{a})(>480 \mathrm{mg} / \mathrm{l})$ and acute phase reactants (erythrocyte sedimentation rate, orosomucoid, platelet count). These results would support the concept that $L p(a)$ is related to acute phase proteins. ${ }^{15} 17$ This correlation was even stronger in patients treated with corticosteroids. No significant correlation was found between high $\mathrm{Lp}(\mathrm{a})$ concentrations (>480 $\mathrm{mg} / \mathrm{l}$ ) and clinical complications or severity of the disease. The small number of patients in this study might have obscured such an association, however.

Our results are in line with previous observations made by Rössner and Löfmark, ${ }^{11}$ who showed that $L p(a)$, detected qualitatively as 'sinking pre-beta lipoprotein', was present more often in patients with polyarthritis than in controls.

The plasma concentrations of cholesterol and triglycerides are remarkably high in the population of northern Sweden. ${ }^{15} 16$ The decreased plasma concentrations of cholesterol, triglycerides, and high density lipoprotein-cholesterol, with sex differences, found in the patients with rheumatoid arthritis in this study are in agreement with previous findings, however. ${ }^{10-12} 1430$

In this study no significant difference was found between the serum concentrations of cholesterol and triglycerides in the untreated patients and those in patients treated with corticosteroids; this is in contrast with another report. $^{31}$ All patients in our study, however, had a disease of median activity and none of the patients was inactive or in remission despite treatment with corticosteroids or remission inducing drugs.

This work was supported by grants from the medical faculty of the University of Umes and from Borgerskapets i Umea forskningsstiftelse för Ekonomi, geriatrik och reumatologi. Mrs Karin $\AA$ berg is gratefully acknowledged for excellent technical assistance.

1 Isomäki H A, Mutru O, Koota K. Death rate and causes of death in patients with rheumatoid arthritis. Scand $f$ death in patients with rhe

2 Allebeck P, Ahlbom A, Allander E. Increased mortality among persons with rheumatoid arthritis, but where RA does not appear on death certificate. Scand $\mathcal{J}$ Rhewmatol 1981; 10: 301-6.

3 Abruzzo J L. Rheumatoid arthritis and mortality. Arthritis Rheum 1982; 25: 1020-3.

4 Prior P, Symmons D P M, Scott D L, Brown R, Hawkins C F. Cause of death in rheumatoid arthritis. Br $\mathcal{F} R$ heumatol 1984; 23: 92-9.

5 Mutru O, Laakso $M$, Isomäki $H$, Koota $K$. Ten year mortality and causes of death in patients with rheumatoid mortality and causes of death in patient

6 Allebeck P. Increased mortality in rheumatoid arthritis. The use of a medical information system for assessment of death risks. Scand I Rheumatol 1982; 11: 81-6.

7 Miller G J, Miller N E. Plasma high density lipoprotein concentration and development of ischemic disease. Lancet 1975; i: $16-19$.

8 Gordon T, Castelli W P, Hjortland M C, Kannel W B, Dawber T R. High density lipoprotein as a protective factor against coronary heart disease. Am $\mathcal{F}$ Med 1977; 62: 707-14.

9 Kottke B A, Zinsmeister A R, Holmes Jr D R, Kneller R W, Hallaway B J, Mao S J T. Apolipoproteins and coronary artery disease. Mayo Clin Proc 1986; 61: 313-20.

10 Wilding $P$, Kendall M J, Holder R, Grimes J A, Farr M. The influence of drugs and disease activity on biochemical and haematological data in rheumatoid arthritis. Clin Chim Acta 1975; 64: 185-94.

11 Rössner S, Löfmark C. Dyslipoproteinaemia in patients with active, chronic polyarthritis a study on serum lipoproteins and triglycerides clearance (intravenous fat tolerance test). Atherosclerosis 1977; 28: 41-52.

12 Svensson K, Lithell H, Hällgren R, Selinus I, Vessby B. Altered serum lipoproteins and enhanced lipoprotein elimination in patients with rheumatoid arthritis and other chronic inflammatory arthritides. I. Relationship to the chronic infammatory arthritides. 1. Relationship to the

3 London M G, Muirden K D, Hewitt J V. Serum cholesterol in rheumatic diseases. $B M \mathcal{F} 1963$; $i$ : $1380-3$.

14 Lorber M, Aviram M, Linn S, Scharf Y, Brook J G. Hypocholesterolaemia and abnormal high-density lipoprotein in rheumatoid arthritis. $\mathrm{Br} \mathcal{F}$ Rheumatol 1985; 24 : $250-5$.

15 Dahlén G $\mathbf{H}$. The pre-beta-1-lipoprotein phenomenon in relation to serum cholesterol and triglyceride levels, the Lp(a) lipoprotein and coronary heart disease. Acta Medica Scandinavica 1974; 570 (suppl): $1-45$

16 Dahlén $G \mathrm{H}$. Lipoprotein (a) in relation to atherosclerotic diseases. In: Widhalm K, Naito H K, eds. Progr Clin Biol Res 1988; 255: 27-36.

17 Kawade M, Maeda S, Abe A, Yamashiro M. Alternation in plasma $\mathbf{L p}(a)$ lipoprotein $\mathbf{L p}(\mathrm{a})$ and acute phase proteins after surgical operation [Abstract]. Clin Chem 1984; 30: 941 (abstr 6).

18 Ropes M W, Bennett G A, Cobb S. Diagnostic criteria for rheumatoid arthritis. Ann Rheum Dis 1959; 18: 49-53.

19 Gaubatz J W, Heideman C, Gotto Jr A M, Morrisett J D, Dahlén G H. Human plasma lipoprotein (a): structural properties. F Biol Chem 1983; 258: 4582-9.

20 Berg $\mathrm{K}$. Inherited lipoprotein variation and atherosclerotic disease. In: Scanu A M, Wissler R W, Getz G S, eds. Biochemistry of atherosclerosis. New York: Dekker, 1979. 419-90.

21 Morton N E, Berg K, Dahlén G, Ferrell R E, Rhoads G G. Genetics of the $\mathrm{Lp}(\mathrm{a})$ lipoprotein in Japanese-Americans. Genetics of the Lpidemiol 1985; 2: 113-21.

22 Utermann G, Kraft H G, Menzel H J, Hopferwieser T, Seitz C. Genetics of the quantitative $L p(a)$ lipoprotein trait. I.
Relation of $L p(a)$ glycoprotein phenotypes to $L p(a)$ lipoprotein concentrations in plasma. Hum Genet 1988; 78: $41-6$.

23 McLean J W, Tomlinson J E, Kuang W-J, et al. cDNA sequence of human apolipoprotein(a) is homologous to plasminogen. Nature 1987; 300: 132-7.

24 Eaton D L, Fless G M, Kohr $\mathbb{W}$ J, et al. Partial amino acid sequence of apolipoprotein(a) shows that it is homologous to plasminogen. Proc Natl Acad Sci USA 1987; 84: 3224-8.

25 Brändström A, Dahlén H G, Rånby M. Lipoprotein (a): in vitro effects on $t-P A$ mediated fibrinolysis. Fibrinolysis vitro effects on t-PA mediat

26 Brown M S, Goldstein J L. Lipoprotein metabolism in the macrophage: implications for cholesterol deposition in macrophage: implications for cholesterol deposition in 223-61.

27 Gianturco S H, Bradley W A, Dahlén G H, et al. Interaction of lipoprotein (a) with murine peritoneal macrophages and cultured human fibroblasts. Arteriosclerosis 1983; 3: 500a .

28 Dahlén G, Ericson C, Berg $K$. In vitro studies of the interaction of isolated $\mathrm{Lp}(\mathrm{a})$ lipoprotein and other serum lipoproteins with glycosaminoglycans. Clin Genet 1978; 14: 36-42.

29 Dahlén G, Ericson C, Berg $\mathrm{K}$. In vitro studies of the interaction of calcium ions and other divalent cations with the $\mathrm{Lp}$ (a) lipoprotein and other isolated serum lipoproteins. Clin Genet 1978; 14: 115-24.

30 Nikkilä E A. Metabolic and endocrine control of plasma high density lipoprotein concentration. In: A M Gotto Jr, N E Miller, M E Oliver, eds. High density lipoprotein
atherosclerosis. Amsterdam: Elsevier, 1978: 177-92.

31 Svensson K, Lithell H, Hällgren R, Vessby B. Serum lipoproteins in rheumatoid arthritis and other inflammatory
arthritides. II. Effects of anti-inflammatory and disease arthritides. II. Effects of anti-inflammatory and disease 1917-20. 